\title{
Efektivitas Penggunaan Aplikasi Google Classroom dalam Meningkatkan Kualitas Pembelajaran PAI Mahasiswa IAIN Curup pada Masa Pandemi Covid-19
}

\author{
Okni Aisa Mutiara Sendi \\ Institut Agama Islam Negeri Curup \\ email: Okniaisa10@gmail.com \\ Eli Susanti \\ Institut Agama Islam Negeri Curup \\ email: eli.susanti68@yahoo.com
}

\begin{abstract}
To avoid the spread of Covid-19, the learning process is carried out through online method, including IAIN Curup. Since April 2020 IAIN Curup has been implementing online learning. During online learning, the lecturers use various online applications to support the learning process so that it can run well. The purpose of this study is to discover how the effectiveness of using Google Classroom application to improve learning quality of IAIN Curup students during the Covid-19 pandemic. This research used qualitative approach, data analysis used qualitative analysis methods by using non-statistical techniques. Reserach data were collected from interviews, observation and documentation. This research shows that the effectiveness of learning by using Google Classroom is quietly effective by using strategies in the form of assignments and observations, problem-based learning models and field experiences, evaluation in the form of questions and product creation. Google classroom has several advantages such as: easy to use, saves mobile data, collects tasks precisely and saves storage memory. Meanwhile, the disadvantage is that communication is not well established
\end{abstract}

Keywords: Effectivity, Google Classroom, Covid-19

Abstrak: Dalam menghindari penyebaran virus covid-19 maka proses pembelajaran dilaksanakan dengan cara online, tidak terkecuali kampus IAIN Curup sejak bulan April 2020 IAIN Curup sudah melaksanakan pembelajaran secara online, dalam pelaksanaan pembelajaran online para dosen menggunakan berbagai aplikasi online untuk menunjang proses pembelajaran agar dapat berjalan dengan baik. Adapun tujuan penelitian ini ingin mengetahui bagaimana efektivitas penggunaan aplikasi google classroom dalam meningkatkan kualitas pembelajaran PAI mahasiswa IAIN Curup pada masa pandemi covid 19. Penelitian ini menggunakan pendekatan kualitatif, untuk analisis data menggunakan metode analisis data yang bersifat kualitatif, teknik yang digunakan adalah teknik data non statistika. Data dikumpulkan dari wawancara, observasi dan dokumentasi. Penelitian ini memperoleh bahwa efektivitas pembelajaran menggunakan google classroom sudah cukup efektif terjalankan dengan menggunakan strategi berbentuk penugasan serta observasi, kemudian model pembelajaran berbasis masalah dan pengalaman lapangan, evaluasi berbentuk soal dan pembuatan produk. Kelebihan dalam penggunaan google classroom mudah digunakan, hemat kuota, pengumpulan tugas tersusun rapih dan hemat memori. Kekurangan dalam penggunaan google classroom, tingkat interaksi dalam berkomunikasi belum terjalan dengan baik.

Kata Kunci: Efektivitas, Google Classroom, Covid-19

Belajea: Jurnal Pendidikan Islam Vol. 6, No 2, 2021; 165-180

p-ISSN 2548-3390; e-ISSN 2548-3404, DOI: 10.29240/belajea.v6i2.3097

available online at:http://journal.staincurup.ac.id/indek.php/belajea 


\section{PENDAHULUAN}

Perubahan besar banyak terjadi pada tahun 2020 ditambah dengan kedatangan wabah baru yang banyak meresahkan seluruh dunia yaitu covid-19, berbagai gaya hidup mulai berubah, hubungan sosialisai terhalang bahkan pendidikan tidak dapat berjalan sebagaimana biasanya. Wabah Covid-19 ini bermula timbul di Wuhan, Cina dan telah diumumkan sebagai pandemi oleh organisasi kesehatan dunia. Demi menanggulangi penyebaran virus covid-19 pemerintah membuat kebijakan seperti isolasi, social and physical distancing hingga pembatasan sosial berskala besar (PSBB). Setiap orang mau tidak mau harus stay in home dengan demikian segala kegiatan harus dilakukan di dalam rumah. Tanpa terkecuali dunia pendidikan proses belajar mengajar harus dilaksanakan dari rumah atau secara online. ${ }^{1}$ Tanpa adanya persiapan yang cukup matang kemudian langsung adanya perubahan secara spontanitas yang tadinya proses pembelajaran berjalan dengan offline kemudian pada masa covid-19 ini dunia pendidikan harus berjalan secara online.

Kampus IAIN Curup sudah menerapkan proses pembelajaran secara online mulai dari bulan April 2020 sehingga proses perkuliahan berlangsung di rumah masingmasing. Tahapan pembelajaran secara online menjadi tantangan baru bagi para pendidik dalam menyampaikan materi perkuliahan sehingga materi yang disampaikan bisa dipahami dan dimengerti dengan baik oleh para mahasiswa dengan harapan pembelajaran yang didapatkan akan berpengaruh positif dalam kehidupan peserta didik. Sehingga kelancaran dalam proses pembelajaran tergantung pada tingkat efektivitas penyampaian materi pembelajaran yang disampaikan. Dengan demikian proses perkuliahan jarak jauh atau online pastinya membutuhkan sarana untuk menyalurkan komunikasi berupa ruang kelas yang bisa dilakukan secara bersama-sama.

Dalam perkuliahan online Dosen IAIN Curup banyak memanfaatkan berbagai aplikasi yang dianggap mudah dan bisa untuk digunakan dalam proses pembelajaran jarak jauh salah satunya pada mata kuliah metode pembelajaran PAI yang juga menggunakan Google Classroom. Google Classrom merupakan sebuah aplikasi yang sengaja dirancang untuk mempermudah interaksi antara pendidik dengan peserta didiknya dalam dunia maya. Aplikasi ini memberikan kesempatan kepada para pendidik untuk membagikan ilmu yang dimilikinya kepada peserta didik kemudian pendidik juga berperan sebagai fasilitator yang memiliki keleluasan waktu dalam mengajar. Akan tetapi pembelajaran menggunakan Google Classsrom hanya bisa digunakan dengan sambungan internet. ${ }^{2}$ Kemudian pembelajaran menggunakan Google Classroom ini dapat menghubungkan dosen dan mahasiswa secara digital. Aplikasi terbaru Google ini selain dapat diakses di PC juga dapat diakses melalui ponsel dan tablet berbasis android dan IOS. Salah satu kecanggihan dari aplikasi ini adalah dapat digunakan secara

${ }^{1}$ Widiyono, Aan. "Efektifitas Perkuliahan Daring (Online) Pada Mahasiswa Pgsd Di Saat Pandemi Covid 19." Jurnal Pendidikan 8.2 (2020): 169-177.

${ }^{2}$ Hammi, Zedha. Implementasi Google Classroom Pada Kelas XI IPA Man 2 Kudus. Diss. Universitas Negeri Semarang, 2017: 27-34 
bersama-sama dalam kelompok. ${ }^{3}$ Dengan harapan proses pembelajaran bisa berjalan dengan baik dan bisa meningkatkan potensi peserta didik. Dalam penggunaan aplikasi Google Classroom pendidik akan lebih muda dalam mengelola pembelajaran secara online dan pendidik juga bisa menyampaikan informasi secara tepat dan akurat kepada peserta didik. ${ }^{4}$

Menurut wikipedia Google Classroom adalah sebuah model pembelajaran yang bersifat campuran yang diperuntukkan untuk setiap ruang lingkup pendidikan. ${ }^{5}$ Dengan demikian Google Classroom merupakan sebuah pembelajaran yang bersifat campuran yang terdiri dari beberapa ruangan dalam pembagian pembelajaran dengan tujuan untuk mempermudah pendidikan serta pemahaman peserta didik. ${ }^{6}$ Dalam pembelajaran menggunakan Google Classroom terdapat banyak keuntungan salah satunya penggunaan aplikasi ini banyak menyediakan fasilitas upload file, kemudian terdapat banyaknya fitur-fitur yang dimiliki oleh Google Classroom yang mempermudah proses pembelajaran. ${ }^{7}$ Salah satu fitur dalam Google Classroom yaitu 1) Assignment (task) yaitu tugas disimpan dan diberi peringkat dalam serangkaian aplikasi produktivitas Google, memungkinkan kolaborasi antara guru dan siswa. 2) Rating (measurement) Google Classroom mendukung banyak hal skema penilaian yang berbeda. Guru dapat memilih untuk melampirkan file ke tugas dimana siswa dapat melihat, mengedit, atau mendapatkan satu salinan. 3) Communication Guru dapat memasang buletin di jalan aliran, dan mahasiswa dapat memberikan komentar itu memungkinkan pertukaran verbal dua arah antara guru dan siswa. ${ }^{8}$ Kemudian didalam Google Classroom guru bisa membuat kelas dengan mudah, hemat waktu dan biaya karena proses pembelajaran bisa dilakukan dalam satu tempat, pengelolaan kelas bisa terkendali dengan baik dengan batuan aktif para peserta didik, berkomunikasi secara langsung dan mampu mengamati keaktifan dalam proses pembelajaran, kelas aman dan gratis. ${ }^{9}$ Adapun manfaat dari

3 Savitri, Desy Irsalina. "Penggunaan Pembelajaran 4.0 Berbantuan Aplikasi Google Classroom Dan Google Form Dalam Mata Kuliah Ilmu Sosial Budaya Dasar." Jurnal Borneo Saintek 2.1 (2019): 20-25.

4 Terasne, Terasne, Et Al. "Pelatihan Pemanfaatan Google Classroom Sebagai Media Pembelajaran Alternatif Pada Masa Covid-19 Bagi Guru." Sasambo: Jurnal Abdimas Journal Of Community Service) 2.3 (2020): 95-100.

${ }^{5}$ Ningrum, Anita. "Analisis Pelaksanaan Pembelajaran Google Classroom Era Pandemic Covid-19 Materi Tata Surya Pada Siswa Kelas Vii Mts Negeri Salatiga Tahun Pelajaran 2019/2020." (2020): 20

${ }^{6}$ Efendi, Yoyon, And Nurul Utami. "Pengukuran Efektifitas Pembelajaran Menggunakan Media E-Learning Google Classroom (Smk Sulthan Muazzamsyah Pekanbaru)." Prosiding Seminar Nasional Computation Technology And Its Aplication. Vol. 1. No. 1. 2019:1

${ }^{7}$ Nurlifa, Alfian, Andy Haryoko, And Ulfa Yuliasari. "Implementasi Google Classroom Sebagai Sarana Pembelajaran Daring Pada Masa Pandemi Covid-19 Di Kabupaten Tuban." Abdi Kami: Jurnal Pengabdian Kepada Masyarakat 3.2 (2020): 161-167.

8 Setiawan, Dimas, And Suluh Langgeng Wicaksono. "Evaluasi Usability Google Classroom Menggunakan System Usability Scale." Walisongo Journal Of Information Technology 2.1 (2020): 71-78.

9 Afrianti, Wahyuni Eka. "Penerapan Google Classroom Dalam Pembelajaran Akuntansi (Studi Pada Program Studi Akuntansi Universitas Islam Indonesia)." (2018): 10-11 
Google Classroom, yaitu: Dapat dipersiapkan dengan mudah, menghemat waktu dan tidak menggunakan kertas, manajemen yang lebih baik. ${ }^{10}$

Google Classroom juga mempunyai kemampuan untuk membuat salinan otomatis dari tugas yang sudah dibuat oleh mahasiswa.11 Dengan demikian pembelajaran jarak jauh pun masih bisa terjalankan dengan baik di mana mahasiswa dan dosen masih bisa berinteraksi dalam dunia maya dan saling memberikan informasi terkait materi pembelajaran. ${ }^{12}$ Pengaplikasian Google Classroom dalam belajar sangatlah muda dilakukan pertama, masuk menggunakan kelas.google.com dan masuk menggunakan akun Google dengan alamat email. Untuk membuat kelas pertama, klik tombol "+" di sebelah alamat email. "Buat kelas" akan muncul dan kemudian tekan. Setelah itu, tambahkan nama kelas. Guru dapat menambahkan rincian tentang kelas, seperti, deskripsi dan instruksi untuk siswa di tab "tentang", dan juga folder Google Drive untuk materi kelas dan dapat melampirkan garis besar kursus dan rencana pelajaran. Akhirnya, kelas siap dan siswa dapat dengan bebas bergabung jika mereka memiliki akun Google institusional dan mereka harus menemukan kode kelas di tab "stream". Banyak kegiatan yang bisa kita lakukan dengan Google Classroom ketika kelas dioperasikan seperti membuat pengumuman, memberikan pengumuman tentang pembaruan kelas, melampirkan file dan materi kelas, membuat, mengunggah tugas untuk siswa pada waktunya untuk diserahkan, mengunduh materi yang telah diunggah oleh guru, membuat pertanyaan untuk didiskusikan dengan guru atau siswa lain, dan menggunakan kembali posting seperti, pengumuman, tugas, dan pertanyaan pada kelas yang lain. ${ }^{13}$

Dengan demikian penggunaan Google Classroom dalam proses pembelajaran menjadi sebuah peluang yang sangat baik untuk digunakan dalam proses pembelajaran. Akan tetapi dalam pencapaian hasil dalam proses pembelajaran harus dibangun secara bersama-sama dalam mecapai tingkat keefektivan pembelajaran secara online baik dari seorang pendidik maupun dari peserta didik. Karena dalam meningkatkan keefektivan proses pembelajaran harus dibangun kerja sama antara pendidik dan peserta didik, walaupun sebagian besar tingkat efektivitas pembelajaran tergantung kepada pendidik dalam melaksanakan pembelajaran terlihat dari rentang waktu pemberian materi pembelajaran, kemudian pengaturan teknik pengajaran serta prosedur pembelajaran di kelas dan penyampaian materi yang bisa menarik peserta didik dalam melangsungkan

${ }^{10}$ Hanifah, Wanda, And K. Y. S. Putri. "Efektivitas Komunikasi Google Classroom Sebagai Media Pembelajaran Jarak Jauh Pada Mahasiswa Ilmu Komunikai Universitas Negeri Jakarta Angkatan 2018." Medialog: Jurnal Ilmu Komunikasi 3.2 (2020): 24-35.

11 Utami, Rini. "Analisis Respon Mahasiswa Terhadap Penggunaan Google Classroom Pada Mata Kuliah Psikologi Pembelajaran Matematika." Prisma, Prosiding Seminar Nasional Matematika. Vol. 2. 2019: 499-500

12 Mulatsih, Bekti. "Application Of Google Classroom, Google Form And Quizizz In Chemical Learning During The Covid-19 Pandemic." Ideguru: Jurnal Karya Ilmiah Guru 5.1 (2020): 16-26.

13 Putra, Ida Nyoman Tri Darma, And Gusti Ayu Meri Aryani. "Pengunaan Googleclassroom Dalam Pembelajaran Bahasa Inggris Pariwisata Pada Mahasiswa Pariwisata Stp Mataram." Jurnal Ilmiah Hospitality 9.1 (2020): 125-134. 
pembelajar semua ini menjadi peran seorang pendidik dalam mengajar. ${ }^{14}$ Tidak dapat dipungkiri bahwa pembelajaran jarak jauh ini menjadi sebuah hal yang baru dirasakan dalam pembelajaran sehingga tingkat keefektivan dalam belajar menjadi sebuah wejangan yang harus disempurnakan secara bersama-sama.

Menurut Slavin keefektivan pembelajaran dapat diukur menggunakan empat indikator sebagai yaitu pertama kualitas pembelajaran, yaitu seberapa besar kadar informasi yang disajikan sehingga siswa dengan mudah dapat mempelajarinya atau tingkat kesalahannya semakin kecil. Semakin kecil tingkat kesalahan yang dilakukan berarti semakin efektif pembelajaran. Kedua kesesuaian tingkat pembelajaran yaitu sejauh mana guru memastikan tingkat kesiapan siswa dalam menerima materi baru. Ketiga insentif yaitu seberapa besar usaha guru memotivasi siswa untuk menyelesaikan atau mengerjakan tugas-tugas dan mempelajari materi yang diberikan. Semakin besar motivasi yang diberikan, maka semakin besar pula keaktifan siswa dengan demikian pembelajaran akan efektif. Dan keempat waktu, yaitu waktu yang dibutuhkan siswa untuk menyelesaikan kegiatan pembelajaran. Pembelajaran akan efektif apabila siswa dapat menyelesaikan pelajaran sesuai dengan waktu yang ditentukan. ${ }^{15}$ Sehingga keefektifan dalam pembelajaran akan terlaksanakan dengan baik apabila terjadi kerjasama yang baik serta adanya kemauan dan semangat belajar dari peserta didik dalam menuntut ilmu sehingga proses pembelajaran yang berlangsung dengan efektif dapat terlaksanakan dengan baik. Dengan demikian setiap pendidik harus mampu mengatur dan mengendalikan kondisi kelas serta memberikan arahan dalam belajar sehingga tingkat pemahaman dan keefektivan dalam pembelajaran akan menjadi lebih terarah dan materi yang akan disampaikan bisa di serap dengan baik oleh para peserta didik. ${ }^{16}$ Dengan demikian penggunaan aplikasi menjadi sebuah penunjang dan penentu keberhasilan pembelajaran. Berkaitan dengan latar belakang masalah ini maka penelitian ini berusaha memperoleh jawaban tentang "Efektivitas Penggunaan Aplikasi Google Classroom Dalam Peningkatan Kualitas Pembelajaran PAI Mahasiswa IAIN Curup Pada Masa Pandemi Covid-19"

\section{METODE PENELITIAN}

Penelitian ini menggunakan penelitian kualitatif dengan menerapkan pendekatan deskriptif kualitatif dengan metode studi kasus yang ada dilapangan. Data dikumpulkan melalui observasi, wawancara dan dokumentasi. Penyajian data berbentuk analisis data non statistik yaitu hanya berupa deskripsi data. Tujuan penelitian ini yaitu

14 Astuti Dwi Aprilia, Prestiadi, Dedi "Efektivitas Penggunaan Media Belajar Dengan Sistem Daring Ditengah Pandemi Covid-19” Prosiding Web-Seminar 20.1 (2020) 978-602.

15 Gunawan, Fransiskus Ivan, And Stefani Geima Sunarman. "Pengembangan Kelas Virtual Dengan Google Classroom Dalam Keterampilan Pemecahan Masalah (Problem Solving) Topik Vektor Pada Siswa Smk Untuk Mendukung Pembelajaran." Prosiding Seminar Nasional Pendidikan Matematika Etnomatnesia. 2018:499

${ }^{16}$ Umairah, Putri, And Zulfah Zulfah. "Peningkatan Motivasi Belajar Menggunakan Google Classroom Ditengah Pandemi Covid-19 Pada Peserta Didik Kelas Xi Ips 4 Sman 1 Bangkinang Kota." Journal On Education 2.3 (2020): 275-285. 
untuk membuat rumusan untuk mengetahui efektivitas pembelajaran menggunakan google classroom dalam meningkatkan kualitas pembelajaran mahasiswa IAIN Curup pada masa pandemi covid-19. Adapun yang menjadi sumber utama yang menjadi narasumber yaitu Dosen IAIN Curup. Selain itu data didapat dari observasi dalam kegiatan perkuliahan secara online. Kemudian dokumentasi di dapat dari data-data jurnal dan buku-buku diperpustakaan. Adapun teknik wawancara yaitu berpedoman pada instrumen yang berbentuk pertanyaan yang diajukan secara langsung kepada informan dan responden ditempat penelitian. Kemudian untuk metode analisis data menggunakan teori Miles dan Huberman yaitu mereduksi data, penyajian data dan pengambilan kesimpulan serta dengan pemeriksaan keabsahan data dengan menggunakan triangulasi.

\section{HASIL DAN PEMBAHASAN}

Hasil penelitian yang didapatkan dilapangan tentang efektivitas penggunaan aplikasi google classroom dalam meningkatkan kualitas pembelajaran mahasiswa IAIN Curup pada masa pandemi covid-19 yang terdiri dari beberapa aspek, yaitu: 1) Efektivitas penggunaan google classroom dalam meningkatkan kualitas pembelajaran mahasiswa IAIN Curup pada masa pandemi, dan 2) Kelebihan dan kekurangan dalam penggunaan google classroom dalam meningkatkan kualitas pembelajaran pada masa pandemi.

\section{Efektivitas Penggunaan Google Classroom Dalam Meningkatkan Kualitas Pembelajaran Mahasiswa PAI IAIN Curup Pada Masa Pandemi}

Berdasarkan hasil wawancara di kampus IAIN Curup dengan dosen pengguna google classroom bahwa pelaksanaan penggunaan Google Classroom sudah berjalan akan tetapi masih perlu di tingkatkan lagi dalam melaksanakan pembelajaran berbasisi online.

\section{Strategi dalam Mengoptimalkan Proses Pembelajaran Menggunakan Google Classroom}

Dalam proses pembelajaran strategi merupakan suatu cara yang dipakai oleh seorang pendidik dalam menyampaikan isi pembelajaran yang dirancang dengan sedemikian rupa supaya peserta didik mampu untuk memahami dengan mudah materi yang akan disampaikan. Banyak strategi yang bisa digunakan dalam penerapan pembelajaran salah satunya dengan menggukan sistem pengelompokan yang mengarah kepada penugasan untuk melaksanakan observasi yang jatuhnya lebih mengarah kepada penerapan model pembelajaran problem solving yang mana pemberian tugas berupa permasalahan yang harus mampu dipecahkan secara bersama-sama. Hal ini senada dengan penyataan dari bapak Mirzon Daheri yang menyatakan bahwa pemberian penugasan pada peserta didik itu lebih kepada arah pembuatan hasil yang nyata atau berupa produk atau hasil dari penyelesaian masalah sehingga pemahaman yang 
didapatkan akan lebih berbekas dan berkesan lama. ${ }^{17}$ Pemahaman dalam pembelajaran akan lebih mudah jika dikerjakan dengan sungguh-sungguh dari berbagai strategi pengajaran yang ada pembuatan sebuah karya ilmiah menjadi strategi yang unggul untuk diterapkan guna untuk melatih tingkat kreatifitas peserta didik dalam mengolah data dan menghasilkan informasi. Yang mana menurut ibu Asri Karolina bahwa penerapan strategi pembelajaran menggunakan google classrom lebih mengarah kepada pembelajaran berbasis produk dan riset penelitian, yang mana pertama pembelajaran akan di jelaskan terlebih dahulu oleh dosen kemudian barulah mahasiswa mulai belajar secara mandiri dalam pengerjaan tugas untuk membuat sebuah prodak berupa bahan ajar seperti video kemudian pembuatan mini riset yang dikumpulkan dalam bentuk laporan. Dengan menggunakan google classroom pengumpulan tugas akan lebih mudan dan lebih rapih karena pengumpulan tugas bisa di bentuk folder tersendiri sesuai judul tugas dan bisa di buka kapan saja serta tidak membutuhkan memori yang cukup karena penyimpanan data tersimpan dengan rapih di dalam google jadi sangat membantu dan menguntungkan dalam proses pendidikan yang lebih nyaman."18

Pembelajaran menggunakan google classroom menjadikan pembelajaran lebih simple dan mudah untuk dijangkau kemudian pembelajaran yang tidak terikat oleh ruang dan waktu sehingga akan memberikan keringanan dalam belajar secara daring ini, hal ini senada dengan ibu Jumira Warlizasusi, bahwa strategi yang digunakan dalam proses pembelajaran menggunakan google classroom banyak menekankan kepada penugasan berdasarkan Silabus dan RPP untuk beberapa kelompok kemudian tugas tersebut dikumpulkan dalam google classroom berdasarkan jenis tugas yang di buat, dengan sistem ini pengumpulan tugas menjadi lebih mudah dan tidak memerlukan ruangan yang banyak dalam mengumpulkan tugas mahasiswa karena semua tugas di simpan dalam google classroom kemudia mahasiswa juga mampu membuka dan melihat berbagai tugas yang telah dikumpulan dengan jaringan yang kurang mendukung pun masih bisa untuk di akses."19

Dengan demikian proses pembelajaran masih bisa terjalankan dengan baik sesuai dengan aturan yang berlandaskan pada Silabus dan RPP sebagai pedoman dalam pembelajaran dengan banyak menekankan pada penugasan yang banyak menghasilkan produk yang memberikan pengalaman nyata bagi pada mahasiswa dalam belajar, kemudian dalam pemberian tugas bersifat kelompok ataupun individu yang mana tertuju untuk mengasa kemandirian mahasiswa dalam belajar dan berfikir kreatif dan aktif dalam pengerjaan tugas yang berbasis pada produk yang mana produk itu di buat berdasarkan hasil observasi langsung yang dilakukan mahasiswa dalam mendapatkan informasi mengenai materi perkulihan. Dengan demikian mahasiswa akan lebih

17 Wawancara Dengan Bapak Mirzon Daheri, Ma. Pd Dosen Pendidikan Agama Islam, 12 Januari 2021

18 Wawancara Dengan Ibu Asri Karolina, M.Pd.I, Dosen Pendidikan Agama Islam, 18 Januari 2021

19 Wawancara Dengan Ibu Dr. Hj. Jumira Warlizasusi, M.Pd Ka. Prodi Manajemen Pendidikan Pascasarjana, 17 Januari 2021 
memahami materi perkuliahan dengan cara terjun langsung dalam mempelajarinya sehingga ilmu yang didapatkan lebih terserap dengan baik.

\section{Model Pembelajaran PAI Yang Digunakan dalam Proses Pembelajaran Menggunakan Google Classroom}

Dalam proses pembelajaran banyak model pembelajaran PAI yaitu pada mata kuliah metode pembelajaran PAI yang digunakan dalam meningkatkan semangat belajar mahasiswa yaitu berupa produk atau pendekatan yang dibuat dan dilakuakan serta di sajikan dalam pembelajaran yang akan memancing kreatifitas serta semangat dalam belajar sehingga mampu mencapai tujuan pembelajaran yang diinginkan. Dalam proses pembelajaran menggunakan google classroom penyampaian pembelajaran harus dapat disajikan dengan cara yang unik dan mudah untuk dipahami oleh siswa sehingga proses pembelajaran akan mudah untuk diikuti oleh para peserta didik. Menurut ibu Asri Karolina mengemukakan bahwa model pembelajaran PAI yaitu pada mata kuliah metode pembelajaran PAI dengan menggunakan google classroom yang sudah diterapkan dengan model pembelajaran berbasis masalah, model pembelajaran mandiri serta berdasarkan masalah. Dengan model pembelajaran ini siswa dituntut untuk belajar mandiri serta mampu untuk menemukan masalah secara sendiri serta mampu memberikan solusi dalam permasalahan tersebut sehingga mahasiswa itu mahasiswa harus kreatif. ${ }^{20}$

Berdasarkan hasil wawancara di atas dapat disimpulkan bahwa model pembelajaran PAI pada mata kuliah metode pembelajaran PAI yang digunakan dalam proses pembelajaran menggunakan google classroom yaitu dengan pembelajaran berbasis masalah, serta pengalaman lapangan dimana dalam pembelajaran ini mahasiswa dituntut untuk belajar secara mandiri dari hasil pengalaman dari lapangan kemudian hasil dari pengamatan lapangan itu di buat sebuah laporan berupa produk yaitu berupa RPP, Silabus, Video serta bahan ajar lainnya seperti Penelitian, yang mana mahasiswa di tuntut untuk mampu memecahkan suatu masalah-masalah yang ada dalam pengamatannya di lapangan. Dengan demikian proses pembelajaran daring pun masih bisa terjalankan dengan efektif walaupun tidak menggunakan model pembelajaran yang bersifat offline karena dalam google classroom pembelajaran berbasis penugasan sehingga model yang digunakan pun disesuaikan dengan media pembelajaran yang di gunakan yang akan memperlancar proses pembelajaran secara efektif.

\section{Tingkat Efektifitas dalam Penggunaan Google Classroom dalam Proses Pembelajaran PAI}

Keberhasilan dalam pembelajaran tergantung dengan tingkat keseriusan dalam belajar yang mana keefektifan dalam belajar menjadi sebuah panutan atau ukuran dalam pencapaian keberhasilan dalam belajar. Efektivitas pembelajaran dapat dipantau dari berbagai kegiatan yang dilakukan peserta didik dalam belajar seperti tingkat keaktifan dalam belajar, serta berbagai respon yang ditimbulkan dalam proses pembelajaran. Akan

${ }^{20}$ Wawancara Dengan Ibu Asri Karolina, M.Pd.I, Dosen Pendidikan Agama Islam, 18 Januari 2021 
tetapi dalam mencapai tingkat keefektifan dalam belajar maka harus dilakukan secara bersama-sama antara guru dan peserta didik. Menurut bapak mirzon tingkat keefektifan pembelajaran pembelajaran pada mata kuliah model pembelajaran PAI dengan menggunakan google classroom cukup baik dengan ketersediaan sinyal yang memadai yang bisa memudahkan siswa mengakses tugas dengan mudah sehingga perkuliahan masih bisa tersampaikan dengan baik. Akan tetapi walaupun begitu untuk tingkat keaktifan serta komunikasi tidak begitu efektif terjalankan dalam aplikasi ini.

Hal ini senada dengan hasil wawancara dengan ibu Asri Karolina, bahwa, pembelajaran menggunakan google classroom sudah sangat efektif terjalankan terlihat dari keaktifan dalam merespon atau tanggapan terhadap pembelajaran yang diberikan dan di sana terlihat dengan jelas dan terdata dengan rapih sehingga dosen dengan mudah memantau keatifan mahasiswa dalam belajar kemudian mahasiswa juga mudah dalam mengaksesnya." 21 Kemudian berdasarkan hasil wawancara dengan bapak Ahmad Danu Saputra yang mengemukakan bahwa memang pada dasarnya pembelajaran yang paling efektif yaitu dengan tatap muka akan tetapi pada masa daring ini untuk tingkat keefektifan pembelajaran jarak jauh dengan penggunaan google classroom sudah sangat efektif di bandingkan dengan penggunaan aplikasi yang lainnya karena dalam segi kemudahan dan kelancaran dalam pembelajaran google classroom menjadi yang terbaik"22

Jadi berdasarkan hasil wawancara di atas dapat peneliti simpulkan, bahwa tingakat keefektifan pembelajaran PAI pada mata kuliah metode pembelajaran PAI didapatkan bahwa penggunakan google classroom sudah cukup efektif terjalankan terlihat dari segi kemudahan penggunaan aplikasi, tanggapan atau respon yang diberikan mahasiswa dalam pembelajaran seperti pengumpulan tugas, kemudain jaringan atau keersediaan sinyal yang baik artinya tidak memerlukan sinyal yang cukup kencang aplikasi ini masih bisa di akses. Untuk segi pelaksanaan pembelajaran google classroom lebih bersifat pemberian tugas dan tidak untuk melakukan komuniakasi atau disukusi jadi dalam segi penugasan google classroom sangat membantu dalam proses pembelajaran yang mana tugas-tugas itu bisa dikumpulkan dengan mudah, rapih, hemat memori serta bisa di akses oleh setiap mahasiswa dimana saja dan kapan saja sehingga pembelajaran dapat berlangsung dimana saja dengan tingakat kefleksibelitas waktu yang diberikan dalam penugasan, akan tetapi dalam segi komunikasi atau berdiskusi dalam google classroom masih terbilang kurang efektif karena tingkat komunikasi hanya dalam pengumpulan tugas serta tanggapan dalam pemberian tugas yang bersifat pasif.

\section{Evaluasi Pembelajaran Menggunakan Google Classroom}

Proses pembelajaran akan menjadi lebih terkendali apabila tingkat keefektifannya terjaga sehingga proses pembelajaran harus selalu di pantau dengan melakukan perubahan berbentuk evalusi dengan tujuan proses pembelajaran akan

${ }^{21}$ Wawancara Dengan Ibu Asri Karolina, M.Pd.I, Dosen Pendidikan Agama Islam, 18 Januari 2021

${ }^{22}$ Wawancara Dengan Bapak Danu Saputra, M.Si Selaku Dosen Perbankan Syariah Iain Curup, 25 Januari 2021 
berjalan lebih efektif dari sebelumnya. Dari hasil wawancara dengan ibu jumira mengemukakan bahwa sistme evaluasi pembelajaran yang dilakukan dengan pemberian tugas, soal dengan diberikan batasan waktu untuk pengumpulannya. Senada dengan ibu asri bahwa evaluasi yang bisa dilakukan dalam aplikasi google classroom dengan pemberian penugasan serta pembuatan prodak atau hasil dari pembelajaran sehingga pemahaman akan lebih melekat diingatan mahasiswa.

Dari hasil wawancara di atas maka dapat disimpulkan bahwa proses evaluasi yang digunakan dalam proses pembelajaran menggunakan google classroom terbilang berpariasi tergantung dengan materi yang di ajarkan oleh dosen. Dalam penilaian pembelajaran pada masa pandemi ini banyak menggunakan evaluasi berbentuk produk yang dihasilkan, yang mana dari produk itu penilaian diambil mengenai sejauh mana pemahaman yang telah di dapat oleh para mahasiswa dalam belajar, sehingga dengan pembuatan produk ini tingkat kecurangan yang di lakukan oleh mahasiswa menjadi lebih kecil. Kemudian evaluasi juga bisa dilakuakan dengan penilaian dari uts ataupun uas yang bersifat pemberian soal-soal yang harus di kerjakan oleh mahasiswa dengan rentang waktu yang telah di tentukan.

\section{Kelebihan dan Kekurangan Penggunaan Google Classroom dalam Meningkatkan Kualitas Pembelajaran pada Masa Pandemi}

\section{Kelebihan Penggunaan Google Classroom dalam Proses Pembelajaran}

Penggunaan media online merupakan hal baru dirasakan dalam dunia pendidikan yang tadinya pendidikan berjalan secara offline dan pada keadaan pandemic ini dunia pendidikan harus di laksanakan dengan cara online, penggunaan media online google classroom menjadi salah satu pilihan yang digunakan dalam proses pembelajaran dalam penerapannya pastilah memiliki keunggulan tersendiri yang bisa menunjang proses pembelajaran menjadi lebih efektif. Menurut ibu asri bahwa banyak kemudahan yang ada dalam aplikasi ini yaitu mudh untuk mengupload file tanpa harus terhalang sinyal kemudian adanya jangka waktu yang diberikan, memiliki ruang memomi yang banyak serta penilaian berbentuk transparan, kuota mendukung, bisa dibuka dengan mudah, dan bisa diakses kapan saja dan dimana saja.

Dari hasil wawancara di atas maka dapat disimpulkan bahwa terdapat beberapa kelebihan dalam penggunaan google classroom dalam proses pembelajaran daring yaitu dari segi kemudahan jaringan sangat baik karena bisa di akses dengan kondisi sinyal yang cukup rendah, kemudian aplikasi mudah di gunakan oleh setiap mahasiswa, kemudian dari sisi ekonomi penggunaan google classroom sangat hemat kuota karena penggunaan kuota internet lebih rendah, penyusunan data-data tugas lebih rapih, penyimpanan memori ringan karena pengumpulan tugas di simpan dalam google jadi tidak memerlukan memori yangbanyak untuk mengumpulkan tugas, dari segi penilaian dalam google classroom bersifat transparan dan waktu pembelajaran bersifat fleksibel jadi proses pembelajaran bisa di lakukan kapan saja dan di mana saja tidak terpatok pada jam pelajaran dengan syarat pengumpulan tugas tepat pada waktu yang telah di tentukan. 


\section{Kekurangan Penggunaan Google Classroom Dalam Proses Pembelajaran}

Dalam penerapan penggunaan media pembelajaran yang baru pastinya memiliki kekurangan yang dirasakan dalam penerapan penggunaan google classroom sebagai media pembelajaran online. Menurut pak Mirzon Daheri tedapat kekurang yang diarasan dalam aplikasi ini yaitu jangkauan interaksi minim, masih ada mahasiswa yang belum menguasai aplikasi ini, kemudian siswa kurang bisa aktif.

Berdasarkan hasil wawancara di atas dapat disimpulkan bahwa terdapat beberapa kekurangan dalam penggunaan google classroom yaitu dalam tingkat interaksi berkomunikasi dalam google classroom belum begitu terjalan dengan baik karena bentuk komunikasi dalam google classroom masih terbilang pasif dan hanya untuk pengumpulan tugas dan tanggapan dalam penugasan yang diberikan dosen jadi untuk tingakt komunikasi yang lebih aktif dosen-dosen banyak menggunakan apliaksi lain seperti Zoom, Google Meat, FB, IG dan Youtube, kemudian kode kelas harus dibagiakan secara terus menerus untuk mengingatkan mahasiswa apabila ada yang menginstal aplikasinya ataupun pembaharuan apliaksi google classroom jadi kode kelas harus dibagikan lagi supaya mahasiswa bisa masuk kembali dalam google classroom, kemudian dalam tingkat pemahaman pengumpulan tugas menggunakan google classroom untuk saat ini masih terdapat mahasiswa yang belum mengerti mengenai sistem pengumpulan tugas dalam google classroom.

Berdasarkan hasil penelitian menunjukkan bahwa strategi dalam mengoptimalkan proses pembelajaran menggunakan google classroom dengan menggunakan strategi penugasan baik itu berbentuk kelompok ataupun individu sudah berjalan dengan baik, dalam proses pembelajaran mahasiswa dituntut untuk belajar mandiri dengan berpatokan pada rps atau silabus yang ada, kemudian dalam pembuatan tugas mahasiswa di tuntut untuk membuat produk yang di dapatkan dari hasil observasi langsung ke lapangan sehingga materi yang di dapatkan lebih bersifat nyata dan jelas, dengan demikian penyampaian materi akan tersampaikan dengan baik kepada para mahasiswa yang melakukan observasi langsung ke lapangan. Kemudian dalam pembelajaran ini model pembelajaran menjadi sebuah cara yang tidak tertinggal dalam keberhasilan pembelajaran daring yang mana dalam pembelajaran daring menggunakan google classroom model pembelajaran yang banyak diterapkan yaitu pembelajaran berbasis masalah, serta pengalaman lapangan dengan demikian pembelajaran ini lebih bersifat nyata. Sehingga dalam segi keefektifan dalam pembelajaran model pembelajaran PAI dengan menggunkan google classroom sudah cukup efektif terjalankan terlihat dari segi kemudahan penggunaan aplikasi, tanggapan atau respon yang diberikan mahasiswa dalam pembelajaran dan pengumpulan tugas tepat waktu.

Kemudian jaringan atau ketersediaan sinyal yang baik artinya tidak memerlukan sinyal yang cukup kencang aplikasi ini masih bisa di akses. Untuk segi pelaksanaan pembelajaran google classroom lebih bersifat pemberian tugas dan tidak untuk melakukan komuniakasi atau disukusi jadi dalam segi penugasan google classroom sangat membantu dalam proses pembelajaran yang mana tugas-tugas itu bisa di kumpulkan dengan mudah, rapih, hemat memori serta bisa di akses oleh setiap mahasiswa di mana saja dan kapan saja sehingga pembelajaran dapat berlangsung di 
mana saja dengan tingakat kefleksibelitas waktu yang diberikan dalam penugasan, akan tetapi dalam segi komunikasi atau berdiskusi dalam google classroom masih terbilang kurang efektif karena tingkat komunikasi hanya dalam pengumpulan tugas serta tanggapan dalam pemberian tugas yang bersifat pasif. Kemudian dalam sistem evaluasi yang digunakan dalam proses pembelajaran menggunakan google classroom terbilang berpariasi tergantung dengan materi yang di ajarkan oleh dosen. Dalam penilaian pembelajaran pada masa pandemi ini banyak menggunakan evaluasi berbentuk produk yang dihasilkan, yang mana dari produk itu penilaian di ambil mengenai sejauh mana pemahaman yang telah di dapat oleh para mahasiswa dalam belajar, sehingga dengan pembuatan produk ini tingkat kecurangan yang di lakukan oleh mahasiswa menjadi lebih kecil. Kemudian evaluasi juga bisa dilakukan dengan penilaian dari UTS ataupun UAS yang bersifat pemberian soal-soal yang harus dikerjakan oleh mahasiswa dengan rentang waktu yang telah ditentukan.

Hal ini sesuai dengan teori menurut Slavin tentang keefektifan pembelajaran dapat diukur menggunakan empat indikator sebagai berikut:

1. Kualitas pembelajaran yaitu seberapa besar kadar informasi yang disajikan sehingga siswa dengan mudah dapat mempelajarinya atau tingkat kesalahannya semakin kecil. Semakin kecil tingkat kesalahan yang dilakukan berarti semakin efektif pembelajaran,

2. Kesesuaian tingkat pembelajaran yaitu sejauh mana guru memastikan tingkat kesiapan siswa dalam menerima materi baru

3. Insentif yaitu seberapa besar usaha guru memotivasi siswa untuk menyelesaikan atau mengerjakan tugas-tugas dan mempelajari materi yang diberikan. Semakin besar motivasi yang diberikan, maka semakin besar pula keaktifan siswa dengan demikian pembelajaran akan efektif.

4. Waktu, yaitu waktu yang dibutuhkan siswa untuk menyelesaikan kegiatan pembelajaran. Pembelajaran akan efektif apabila siswa dapat menyelesaikan pelajaran sesuai dengan waktu yang ditentukan ${ }^{23}$

Dapat dipahami bahwa proses pembelajaran menggunakan aplikasi google classroom pada masa pandemi covid-19 di IAIN Curup sudah terjalankan dengan cukup efektif dilihat dari hasil observasi bahwa penyampaian pembelajaran sudah terjalankan dengan baik dengan berpatokan pada RPS kemudian mahasiswa juga dituntut untuk aktif dalam belajar contohnya dalam segi penugasan berupa pembuatan produk dari hasil observasi ke lapangan disini dapat kita lihat bahwa kualitas pembelajaran yang telah disampaikan sudah sangat baik yang mana mahasiswa akan lebih memahami materi pelajaran dengan cara terjun langsung kelapangan dan di praktekkan dengan pembuatan produk atau hasil pengamatan. Kemudian dalam

${ }^{23}$ Gunawan, Fransiskus Ivan, And Stefani Geima Sunarman. "Pengembangan Kelas Virtual Dengan Google Classroom Dalam Keterampilan Pemecahan Masalah (Problem Solving) Topik Vektor Pada Siswa SMK Untuk Mendukung Pembelajaran." Prosiding Seminar Nasional Pendidikan Matematika Etnomatnesia. 2018. 
tingakat kesiapan mahasiswa dalam menerima materi baru dapat dirasakan dengan respon dan antusias dalam pengerjan tugas yang diberikan serta respon yang ditimpulkan dalam pelakasaan tugas dan pengumpulan tugas tepat waktu. Dengan demikian walapun pembelajaran daring semangat belajar para mahasiswa tetap ada dengan terus melaksanakan kewajiban belajar dan melakukan tugas-tugas yang diberikan dengan rentang waktu yang bersifat fleksibel. Dengan demikian pembelajaran bisa terjalankan dengan efektif apabila tingkat kerjasama antar dosen dan mahasiswa terjalan dengan baik.

Kemudian dari segi penggunaan google classroom dalam proses pembelajaran daring ini sangat membantu para tenaga pendidik dalam memahi mahasiswa dalam melaksanakan perkuliahan secara online bahwa sebagaimana kita ketahui bahwa pembelajaran berbasis daring ini banyak memangkas perekonomian dengan pengeluaran kuota internet yang harus ada untuk bisa melaksanakan perkuliahan daring. Dengan pengguaan google classroom ini merupakan sebuah bentuk kepedulian dosen terhadap perekonomian yang dialami mahasiswa. Kemudain dalam aplikasi google classroom terdapat beberapa keuntungan yaitu aplikasinya mudah digunakan, sederhana dan terdapat banyak fitur-fitur pendukung dalam belajar. Adapun manfaat dari Google Classroom, yaitu:

1. Dapat dipersiapkan dengan mudah. Pengajar dapat menyiapkan kelas dan mengundang siswa atau mahasiswa dan asisten pengajar. Di halaman Kelas, mereka dapat berbagi informasi, tugas, dan materi.

2. Menghemat waktu dan tidak menggunakan kertas. Pengajar dapat membuat kelas, menugaskan tugas, berkomunikasi dan mengelola, semuanya di satu tempat.

3. Manajemen yang lebih baik. Siswa atau mahasiswa dapat melihat tugas pada halaman tugas, dalam ruang kelas, atau pada kalender kelas. Semua materi kelas disimpan secara otomatis di folder Google Drive.

4. Meningkatkan komunikasi dan masukan. Pengajar dapat membuat tugas, mengirim pengumuman, dan memulai diskusi kelas secara langsung. Siswa atau mahasiswa dapat berbagi materi satu sama lain dan berinteraksi dalam kelas atau melalui email. Pengajar juga dapat dengan cepat melihat siapa yang telah dan belum menyelesaikan tugas, dan segera memberikan nilai dan input waktu nyata.

5. Dapat bekerja dengan aplikasi yang Anda gunakan. Seperti dengan Google Documents, Kalender, Gmail, Drive, dan Formulir.

6. Kelas yang terjangkau dan aman. Karena disediakan gratis untuk sekolah, organisasi nirlaba, dan individu. Kelas tidak mengandung iklan dan tidak pernah menggunakan konten atau data siswa atau mahasiswa anda untuk tujuan iklan. ${ }^{24}$

${ }^{24}$ Hanifah, Wanda, And K. Y. S. Putri. "Efektivitas Komunikasi Google Classroom Sebagai Media Pembelajaran Jarak Jauh Pada Mahasiswa Ilmu Komunikai Universitas Negeri Jakarta Angkatan 2018." Medialog: Jurnal Ilmu Komunikasi 3.2 (2020): 24-35. 
Dengan demikian dapat dipahami dari hasil penelitian bawa terdapat beberapa keunggulan dalam penggunaan google classroom dalam pembelajaran daring pada mata kuliah metode pembelajaran PAI yaitu dari segi kemudahan jaringan sangat baik karena bisa di akses dengan kondisi sinyal yang cukup rendah, kemudian aplikasi mudah di gunakan oleh setiap mahasiswa, kemudian dari sisi ekonomi penggunaan google classrom sangat hemat kuota karena penggunaan kuota internet lebih rendah, penyusunan data-data tugas lebih rapih, penyimpanan memori ringan karena pengumpulan tugas di simpan dalam google jadi tidak memerlukan memori yang banyak untuk mengumpulkan tugas, dari segi penilaian dalam google classroom bersifat transparan dan waktu pembelajaran bersifat fleksibel jadi proses pembelajaran bisa di lakukan kapan saja dan di mana saja tidak terpatok pada jam pelajaran dengan syarat pengumpulan tugas tepat pada waktu yang telah di tentukan. Selain itu dalam sebuah keunggulan pastinya terdapat kekurangan, terdapat beberapa kekurangan dalam penggunaan google classroom dalam proses pembelajaran daring yaitu dalam tingkat interaksi berkomunikasi dalam google classroom belum begitu terjalan dengan baik karena bentuk komunikasi dalam google classroom masih terbilang pasif dan hanya untuk pengumpulan tugas dan tanggapan dalam penugasan yang diberikan dosen jadi untuk tingkat komunikasi yang lebih aktif dosen-dosen banyak menggunakan apliaksi lain seperti Zoom, Google Meat, FB, IG dan Youtube, kemudian kode kelas harus dibagikan secara terus menerus untuk mengingatkan mahasiswa apabila ada yang menginstal aplikasinya ataupun pembaharuan aplikasi google classroom jadi kode kelas harus dibagikan lagi supaya mahasiswa bisa masuk kembali dalam google classroom, kemudian dalam tingkat pemahaman pengumpulan tugas menggunakan google classroom untuk saat ini masih terdapat mahasiswa yang belum mengerti mengenai sistem pengumpulan tugas dalam google classroom.

\section{PENUTUP}

Berdasarkan hasil penelitian yang telah peneliti lakukan mengenai efektifitas penggunaan aplikasi google classroom dalam peningkatan kualitas pembelajaran PAI mahasiswa IAIN Curup pada masa pandemic covid-19, maka dapat ditarik beberapa kesimpulan sebagai berikut: Pertama, strategi dalam mengoptimalkan proses pembelajaran PAI menggunakan google classroom lebih terarah pada teknik penugasan baik itu berbentuk kelompok ataupun individu, dalam pembelajaran ini mahasiswa di tuntut untuk belajar mandiri dengan berpatokan pada rps yang ada untuk pembuatan tugas yang berupa produk yang di dapatkan dari hasil observasi langsung ke lapangan. Kemudian model pembelajaran PAI yang di gunakan yaitu pembelajaran berbasis masalah, serta pengalaman lapangan. Untuk keefektifan dalam pembelajaran menggunkan google classroom sudah cukup efektif terjalankan terlihat dari segi kemudahan penggunaan aplikasi, tanggapan atau respon yang diberikan mahasiswa dalam pembelajaran dan pengumpulan tugas tepat waktu. Kemudian evaluasi pembelajaran dalam google classroom sudah dilakukan dengan berbagai cara seperti pembuatan produk dan soal-soal. Kedua, kelebihan penggunaan google classroom dalam proses pembelajaran lebih murah, mudah di gunakan, fleksibelitas waktu yang baik, kapasitas memori yang di butuhkan rendah. Sedangkan kekurangan dari google 
classroom tidak bisa untuk berkomunikasi aktif, tidak bisa tatap muka, kode kelas harus disebar terus menerus.

\section{DAFTAR PUSTAKA}

Afrianti, Wahyuni Eka. "Penerapan Google Classroom Dalam Pembelajaran Akuntansi (Studi Pada Program Studi Akuntansi Universitas Islam Indonesia)." (2018).

Astuti Dwi Aprilia, Prestiadi, Dedi "Efektivitas Penggunaan Media Belajar Dengan Sistem Daring Ditengah Pandemi Covid-19" Prosiding Web-Seminar 20.1 (2020)

Efendi, Yoyon, And Nurul Utami. "Pengukuran Efektifitas Pembelajaran Menggunakan Media E-Learning Google Classroom (Smk Sulthan Muazzamsyah Pekanbaru)." Prosiding Seminar Nasional Computation Technology And Its Aplication. Vol. 1. No. 1. 2019.

Gunawan, Fransiskus Ivan, And Stefani Geima Sunarman. "Pengembangan Kelas Virtual Dengan Google Classroom Dalam Keterampilan Pemecahan Masalah (Problem Solving) Topik Vektor Pada Siswa Smk Untuk Mendukung Pembelajaran." Prosiding Seminar Nasional Pendidikan Matematika Etnomatnesia. 2018.

Hammi, Zedha. Implementasi Google Classroom Pada Kelas Xi Ipa Man 2 Kudus. Diss. Universitas Negeri Semarang, 2017

Hanifah, Wanda, And K. Y. S. Putri. "Efektivitas Komunikasi Google Classroom Sebagai Media Pembelajaran Jarak Jauh Pada Mahasiswa Ilmu Komunikai Universitas Negeri Jakarta Angkatan 2018." Medialog: Jurnal Ilmu Komunikasi 3.2 (2020)

Mulatsih, Bekti. "Application Of Google Classroom, Google Form And Quizizz In Chemical Learning During The Covid-19 Pandemic." Ideguru: Jurnal Karya Ilmiah Guru 5.1 (2020)

Ningrum, Anita. "Analisis Pelaksanaan Pembelajaran Google Classroom Era Pandemic Covid-19 Materi Tata Surya Pada Siswa Kelas Vii Mts Negeri Salatiga Tahun Pelajaran 2019/2020." (2020)

Nurlifa, Alfian, Andy Haryoko, And Ulfa Yuliasari. "Implementasi Google Classroom Sebagai Sarana Pembelajaran Daring Pada Masa Pandemi Covid-19 Di Kabupaten Tuban." Abdi Kami: Jurnal Pengabdian Kepada Masyarakat 3.2 (2020)

Putra, Ida Nyoman Tri Darma, And Gusti Ayu Meri Aryani. "Pengunaan Googleclassroom Dalam Pembelajaran Bahasa Inggris Pariwisata Pada Mahasiswa Pariwisata Stp Mataram." Jurnal Ilmiah Hospitality 9.1 (2020)

Savitri, Desy Irsalina. "Penggunaan Pembelajaran 4.0 Berbantuan Aplikasi Google Classroom Dan Google Form Dalam Mata Kuliah Ilmu Sosial Budaya Dasar." Jurnal Borneo Saintek 2.1 (2019) 
194 | Belajea: Jurnal Pendidikan Islam, Vol. 6, No. 2, 2021

Setiawan, Dimas, And Suluh Langgeng Wicaksono. "Evaluasi Usability Google Classroom Menggunakan System Usability Scale." Walisongo Journal Of Information Technology 2.1 (2020)

Terasne, Terasne, Et Al. "Pelatihan Pemanfaatan Google Classroom Sebagai Media Pembelajaran Alternatif Pada Masa Covid-19 Bagi Guru." Sasambo: Jurnal Abdimas (Journal Of Community Service) 2.3 (2020)

Umairah, Putri, And Zulfah Zulfah. "Peningkatan Motivasi Belajar Menggunakan Google Classroom Ditengah Pandemi Covid-19 Pada Peserta Didik Kelas Xi Ips 4 Sman 1 Bangkinang Kota." Journal On Education 2.3 (2020)

Utami, Rini. "Analisis Respon Mahasiswa Terhadap Penggunaan Google Classroom Pada Mata Kuliah Psikologi Pembelajaran Matematika." Prisma, Prosiding Seminar Nasional Matematike. Vol. 2. 2019.

Widiyono, Aan. "Efektifitas Perkuliahan Daring (Online) Pada Mahasiswa Pgsd Di Saat Pandemi Covid 19." Jurnal Pendidikan 8.2 (2020) 